\title{
Some like it hot: the protozooplankton-copepod link in a warming ocean
}

\author{
N. Aberle ${ }^{1, *}$, A. M. Malzahn ${ }^{2}$, A. M. Lewandowska ${ }^{3,4}$, U. Sommer ${ }^{3}$ \\ ${ }^{1}$ Alfred Wegener Institute Helmholtz Centre for Polar and Marine Research, Biologische Anstalt Helgoland, Postfach 180, \\ 27483 Helgoland, Germany \\ ${ }^{2}$ Sultan Qaboos University, College of Agricultural and Marine Sciences, Dept. of Marine Sciences and Fisheries, PO Box 34 \\ 123 Al-Khoud, Sultanate of Oman \\ ${ }^{3}$ GEOMAR Helmholtz Centre for Ocean Research, Düsternbrooker Weg 20, 24105 Kiel, Germany \\ ${ }^{4}$ Institute for Chemistry and Biology of the Marine Environment (ICBM-Terramare), \\ Carl von Ossietzky University of Oldenburg, Schleusenstrasse 1, 26382 Wilhelmshaven, Germany
}

\begin{abstract}
The combined effects of warming and densities of overwintering copepods on the spring succession of Baltic Sea plankton were investigated using indoor mesocosms. Three zooplankton densities $\left(1.5,4\right.$ and 10 copepods $\left.l^{-1}\right)$ and 2 temperature levels $\left(\Delta 0^{\circ} \mathrm{C}\right.$ and $\Delta 6^{\circ} \mathrm{C}_{;} 0^{\circ} \mathrm{C}$ and $6^{\circ} \mathrm{C}$ above present-day temperatures in the Kiel Bight) were chosen. Both the timing and the duration of the protozooplankton (PZP) bloom were significantly affected by temperature, but not by copepod density. In contrast, the bloom intensity of PZP was highly affected by the factors temperature and copepod density and their interaction. This suggests that under elevated temperature conditions PZP grows faster, but, at the same time, is subject to higher top-down control by copepods. At low temperatures and low copepod densities, PZP, in turn, fully escaped from copepod predation. Further changes in copepod overwintering densities resulted in a strong suppression of ciliates, of which small-sized ciliates $(<30 \mu \mathrm{m})$ were especially vulnerable to copepod predation, while other PZP size classes remained unaffected. In conclusion, results point at a pivotal regulating role of overwintering copepods under future warming conditions. Further, warming was shown to cause a distinct match between phytoplankton and PZP, thus strengthening trophic pathways through PZP. Our findings are discussed in the context of the 'trophic link-sink' debate by considering potential alterations in the flux of matter and energy up the food web.
\end{abstract}

KEY WORDS: Climate change - Global warming $\cdot$ Protoperidinium bipes $\cdot$ Lohmaniella oviformis Trophic sink · Trophic link · Zooplankton grazing $\cdot$ Trophic intermediary

Resale or republication not permitted without written consent of the publisher

\section{INTRODUCTION}

The phytoplankton spring bloom is a major, recurrent phenomena in temperate and cold planktonic systems, which fuels secondary production (Straile \& Adrian 2000, Edwards \& Richardson 2004, Wiltshire et al. 2008, Sommer \& Lewandowska 2011). Global warming is known to result in an earlier onset of biological spring events, e.g. advancement of the phytoplankton spring bloom (Weyhenmeyer et al. 1999, Gerten \& Adrian 2001, Weyhenmeyer 2001, Sommer et al. 2012, Winder et al. 2012). However, a delayed timing of spring bloom phenomena has also been reported, e.g. in the North Sea (Wiltshire \& Manly 2004). Increased grazing by overwintering zooplankton at elevated temperatures has been suggested as an explanation for this delay. Only when light conditions improve during late spring does the growth rate of primary producers exceed the grazing losses of zooplankton (Rose \& Caron 2007), thus opening a 'loophole' for the phytoplankton to form a bloom (Irigoien et al. 2005). This is related to the different 
temperature dependencies of photoautotrophic and heterotrophic processes. While light-limited photosynthesis is only weakly responsive to warming, the physiology and metabolism of heterotrophs is highly temperature-dependent (see the 'metabolic theory of ecology [MTE]' of Brown et al. [2004]). Such an unequal response of autotrophs and heterotrophs to warming is assumed to create shifts in the trophodynamic interactions of plankton (McGowan et al. 2003, Smol et al. 2005). Further, trophic pathways through protozooplankton (PZP) might be enhanced with warming due to short generation times and strong responses of PZP to elevated temperature conditions (Mueller \& Geller 1993, Weisse \& Montagnes 1998, Montagnes \& Lessard 1999, Montagnes et al. 2003). In the light of a winter warming scenario for northern-central Europe (IPCC 2007), reduced timelags between phytoplankton and PZP might cause imbalances between growth and the removal of phytoplankton, thus affecting phytoplankton bloom dynamics (Wiltshire et al. 2008) and composition (Keller et al. 1999, Sommer \& Lengfellner 2008).

Traditionally, filter-feeding copepods have been considered to graze predominantly on large phytoplankton. This picture has changed during the last decades, and feeding modes of most copepods are now considered flexible. Omnivory is a common feature of copepods, and PZP (e.g. ciliates and heterotrophic flagellates) are known to contribute substantially to copepod diets (Jonsson \& Tiselius 1990, Stoecker \& Capuzzo 1990, Kleppel 1993, Calbet \& Landry 1999, Sommer et al. 2005). In general, the feeding preferences of copepods are considered to depend strongly on the abundance and taxonomic composition of phytoplankton and PZP. Further, the role of PZP in improving the food quality for copepods by buffering nutritional imbalances at the interface between primary production and consumption ('trophic upgrading') has been stressed (Malzahn et al. 2010). On the other hand, PZP have the potential to modulate or even suppress phytoplankton blooms (Irigoien et al. 2005, Sherr \& Sherr 2009, Löder et al. 2011). While ciliates feed mainly on nanoplankton (Jonsson 1986), heterotrophic dinoflagellates are able to suppress large, bloom-forming diatoms (Sherr \& Sherr 2007).

In spring, overwintering copepod densities are usually low, and the copepods' numerical response to increasing food sources is slow. In contrast, PZP grow instantaneously in response to increasing food sources (Johansson et al. 2004), often at rates comparable to phytoplankton growth rates, especially under warm conditions (Fenchel \& Finlay 1983,
Mueller \& Geller 1993, Montagnes \& Lessard 1999). In case of a tighter coupling between PZP and its algal food sources under elevated temperature conditions, enhanced feeding competition between microand mesozooplankton seems plausible. Such an enhanced trophic overlap could, in turn, enable PZP to function as a 'trophic sink' rather than a 'trophic link', thus reducing energy flow up the food web (Gifford 1991, Rollwagen-Bollens et al. 2011).

Experimental studies addressing the combined role of overwintering micro- and mesozooplankton on spring plankton dynamics are rare. The present study is unique in that it combines 2 driving factors affecting plankton dynamics during spring bloom formation: (1) temperature and (2) the density of overwintering copepods, in a fully factorial design.

To elucidate the interactions between PZP and copepods and their consequences for plankton dynamics during spring, we addressed the following hypotheses on the combined effects of warming and copepod density:

(1) High overwintering copepod densities will affect PZP biomass $\left(B_{\mathrm{P}}\right)$ leading to shifts in PZP community composition and/or size classes

(2) Warming at high copepod densities leads to a stronger top-down control of PZP by copepods (PZP functions as a 'trophic link')

(3) Warming at low copepod densities leads to an earlier occurrence of PZP and reduced time-lags between phytoplankton and PZP production (PZP functions as a 'trophic sink').

\section{MATERIALS AND METHODS}

\section{Experimental design}

A detailed description of the experimental set-up in 2009 is given by Sommer \& Lewandowska (2011). Twelve mesocosms with a volume of $1400 \mathrm{l}$ each and a depth of $1 \mathrm{~m}$ were placed in 4 temperaturecontrolled rooms. We used 3 zooplankton levels (1.5, 4 and 10 copepods $\mathrm{l}^{-1}$ ) and 2 temperature levels, in the following called $\Delta 0^{\circ} \mathrm{C}$ and $\Delta 6^{\circ} \mathrm{C}\left(0^{\circ} \mathrm{C}\right.$ and $6^{\circ} \mathrm{C}$ above the present-day temperature scenario for the Kiel Bight). Actual temperatures in the 12 mesocosms at ambient $\left(\Delta 0^{\circ} \mathrm{C}\right)$ and elevated $\left(\Delta 6^{\circ} \mathrm{C}\right)$ temperature regimes are shown in Fig. 1. Three zooplankton levels where established per room, and 2 of the rooms were run at the same temperature regimes (for each temperature level). All mesocosms were filled simultaneously with water from the Kiel Bight, Baltic Sea, assuring similar initial conditions. Damage through 


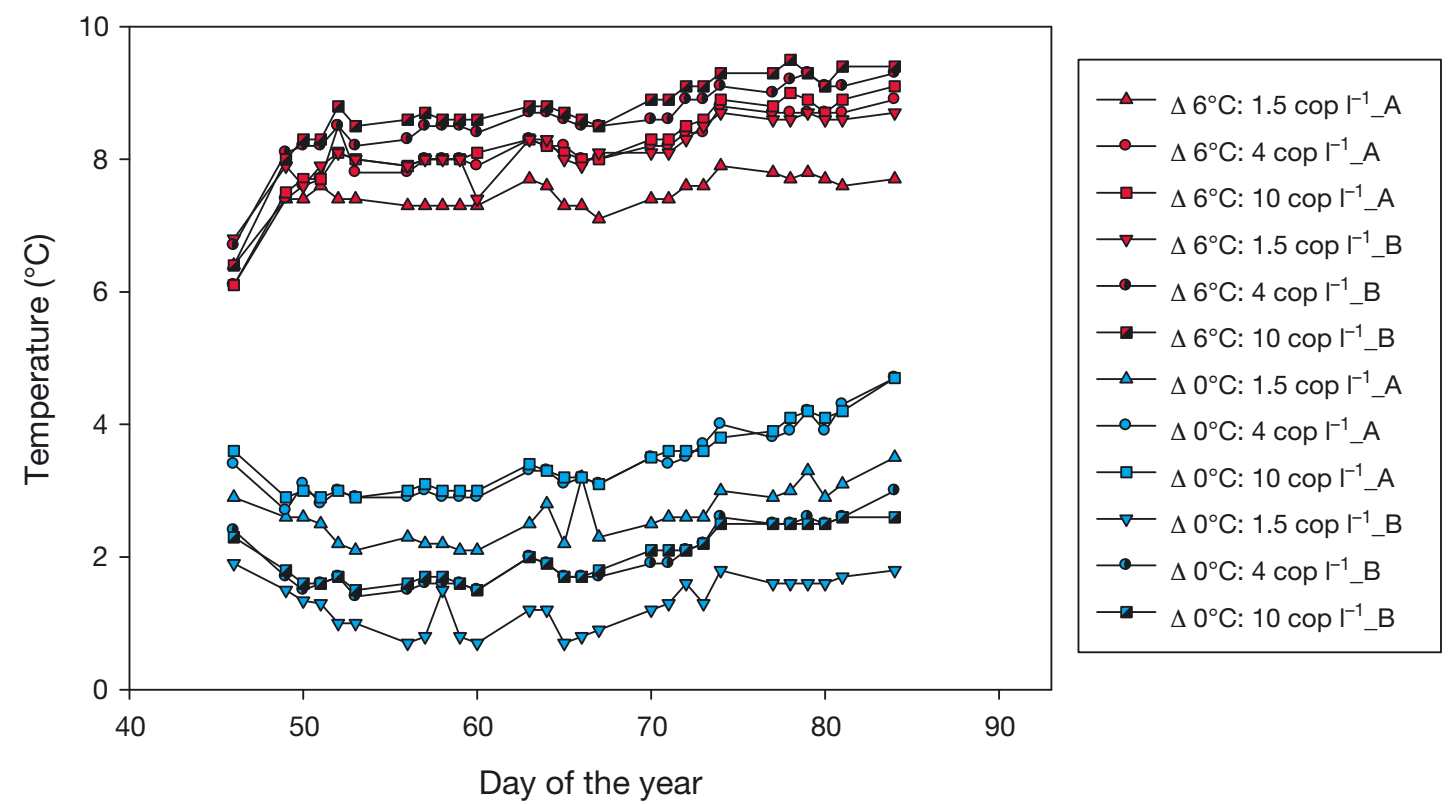

Fig. 1. Actual temperatures in the 12 mesocosms at ambient $\left(\Delta 0^{\circ} \mathrm{C}\right)$ and elevated $\left(\Delta 6^{\circ} \mathrm{C}\right)$ temperature regimes with different copepod densities (replicates A and B) during the duration of the experiment

the pumping procedure was tolerable for phytoplankton and PZP, but mesozooplankton organisms did not survive this transfer. Mesozooplankton, comprising mainly copepods (70\% Acartia sp., 17\% Oithona similis, $7 \%$ Pseudocalanus sp., 3\% Temora longicornis and $3 \%$ Centropages hamatus), was added from net-catches at density ranges similar to the ones found in the Kiel Bight in spring (Behrends 1996). The copepod composition remained relatively constant throughout the experiment, and no great changes were observed in any of the 12 mesocosms. Details on phytoplankton and mesozooplankton composition changes have been given in previous publications dealing with the same mesocosm study. Changes in phytoplankton composition and size ranges are found in the study by Sommer \& Lewandowska (2011) Furthermore, the paper by Lewandowska et al. (2014) provides details on the zooplankton and stresses that composition did not change during the course of the mesocosm experiment.

The $\Delta 0^{\circ} \mathrm{C}$ temperature treatment was based on the average seasonal pattern of surface temperatures for the Kiel Bight during the years 1993-2002. The elevated $\Delta 6^{\circ} \mathrm{C}$ temperature treatment was intended to simulate future warming scenarios predicted by the IPCC (2007) for the end of the century. The natural seasonal temperature increase during spring was simulated starting with mean temperatures of $2.4^{\circ} \mathrm{C}$ $\left(\Delta 0^{\circ} \mathrm{C}\right)$ and $8.4^{\circ} \mathrm{C}\left(\Delta 6^{\circ} \mathrm{C}\right)$, respectively. For details on the actual temperature regimes in the mesocosms see Fig. 1.
Light was supplied by computer-controlled light units (Profilux II, GHL Groß Hard- and Software Logistics) above each mesocosm, simulating daily triangular light curves, and the seasonal change in light climate was calculated using the astronomic model published by Brock (1981).

The starting date for the light and temperature programs was set to a theoretical start on 15 February (Day-of-the-year [DOY] 46) in order to allow comparisons with previous experiments using the same mesocosm set-up (Sommer et al. 2012). The actual starting date was 9 January 2009. The experiment was terminated after $38 \mathrm{~d}$.

Details on phytoplankton and copepod sampling are given by Sommer \& Lewandowska (2011).

\section{PZP sampling and enumeration}

Weekly seawater samples from the mesocosms were taken for PZP enumeration and identification. The seawater was transferred to $250 \mathrm{ml}$ bottles, fixed with acidic Lugol's iodine ( $2 \%$ final concentration), settled in $100 \mathrm{ml}$ sedimentation chambers and counted with a Zeiss Axiovert 135 at 200× magnification using an inverted microscope technique (Utermöhl 1958). Identification to the lowest possible taxonomic level (species or genus level) was made using Kahl (1932), Foissner et al. (1991-1995), Tomas (1996), Strüder-Kypke et al. (2002), Scott (2005). Geometric proxies following Hillebrand et al. (1999) where used 
for biovolume calculations and thereafter converted into carbon biomass using the conversion factors given in Putt \& Stoecker (1989).

\section{Statistical analysis}

We fitted sigmoidal curves to the temporal evolution of cumulative PZP biomass; $f(x)=a /\{1+$ $\left.\exp \left[-\left(x-x_{0}\right) / b\right]\right\}$, where $x$ is time. As sigmoidal curves are derivatives of bell-shaped curves, we consider the inflection point $\left(x_{0}\right)$ as the bloom timing and $b$ as the bloom duration. We used ANCOVAs for further investigation on the effects of temperature (categorical factor) and log copepod densities (quantitative factor). Further interactions between the 2 factors on the bloom timing $\left(x_{0}\right)$, the bloom duration $(b)$ and the bloom intensity $\left(B_{\mathrm{P}}\right.$ at $D_{\max }$, the day when $B_{\mathrm{P}}$ maxima were reached) were analyzed. We excluded $2 x_{0}$ values and $1 b$ value from the analysis, since they did not fit the sigmoidal curve and were hence omitted from the ANCOVA. Both cases were $\Delta 0^{\circ} \mathrm{C}$ mesocosms, one with low and one with intermediate copepod densities. We used ANCOVAs to evaluate the influence of temperature (categorical factor) and log copepod densities (quantitative factor), as well as interactions between the 2 factors, on the relative biomass contribution of dinoflagellates $>30 \mu \mathrm{m}$, dinoflagellates $<30 \mu \mathrm{m}$, ciliates $>30 \mu \mathrm{m}$ and ciliates $<30 \mu \mathrm{m}$ at the biomass maximum, which turned out to always be the nearest sampling date to $x_{0}$ derived from the non-linear fitting described above. We applied a Bonferroni correction to the significance level $\alpha$ ( $\alpha$ /number of tests). This was necessary due to the multiple tests performed on the same dataset. Hence, we set an $\alpha$ level of 0.025 for timing ( 2 tests) and duration of the bloom and an $\alpha$ level of 0.01 (5 tests) for the 5 biomass-related measures (total biomass, small ciliates, large ciliates, small dinoflagellates and large dinoflagellates). A list of variables, including abbreviations and units, is given in Table 1. We used SigmaPlot 10.0 for the non-linear curve fitting and Statistica 8.0 for the ANCOVAs.

\section{RESULTS}

In the warm mesocosms $\left(\Delta 6^{\circ} \mathrm{C}\right) B_{\mathrm{P}}$ showed a clear numerical response to increasing phytoplankton availability. Shortly after the peak of the phytoplankton bloom, PZP reached $D_{\max }$ on DOY 58 and decreased below the initial levels
Table 1. List of variables. PZP: protozooplankton; DOY: dayof-the-year

\begin{tabular}{|lcc|}
\hline Name & Abbreviation & Unit \\
\hline PZP biomass & $B_{\mathrm{P}}$ & $\mu \mathrm{g} \mathrm{Cl}^{-1}$ \\
Timing of the $B_{\mathrm{P}}$ maximum & $D_{\max }$ & $\mathrm{DOY}$ \\
Bloom timing & $x_{0}$ & $\mathrm{DOY}$ \\
Bloom duration & $b$ & $\mathrm{~d}$ \\
Bloom intensity & $B_{\mathrm{P}}$ at $D_{\max }$ & $\mu \mathrm{C} \mathrm{Cl}^{-1}$ \\
\hline
\end{tabular}

thereafter (Table 2, Fig. 2A-C). In the cold mesocosms, $B_{\mathrm{P}}$ responded more slowly to increases in phytoplankton biomass, and clear increases could only be observed in the mesocosms with low and moderate copepod densities (Fig. 2D,E). Here, $D_{\max }$ was reached at DOY 65 or 79 (Table 2). In the cold mesocosms with high copepod densities, $B_{\mathrm{P}}$ increased only slightly, and the biomass levels reached were much lower than those in the low and moderate copepod density treatments (Fig. 2F).

The bloom intensity (i.e. the $B_{\mathrm{P}}$ at $D_{\text {max }}$ ) was significantly affected by both temperature and copepod densities as well as their interaction (Table 3). At both temperatures, increasing copepod abundance decreased the bloom intensity; however, the decreasing effect was stronger in the $\Delta 0^{\circ} \mathrm{C}$ treatment (Fig. 3). $x_{0}$ and $b$ were not influenced by copepod biomass, but were significantly accelerated and shortened in the warm mesocosms (Table 3). Species-specific PZP biomass at $D_{\max }$ is shown in Fig. 4. In general, the small strobilidiid ciliate Lohmaniella oviformis dominated the spring PZP bloom community in all 12 mesocosms, reaching its highest $B_{\mathrm{P}}$ at $D_{\max }$ in

Table 2. Protozooplankton bloom timing and duration (see Table 1) at mesocosm temperatures and copepod densities. $\Delta T$ : temperature elevation; copepod density: initial copepod density in the mesocosm; ns: not significant

\begin{tabular}{|c|c|c|c|c|c|c|}
\hline $\begin{array}{l}\Delta T \\
\left({ }^{\circ} \mathrm{C}\right)\end{array}$ & $\begin{array}{c}\text { Copepod } \\
\text { density } \\
\left(\text { ind. } 1^{-1}\right)\end{array}$ & $\begin{array}{c}x_{0} \\
\text { (DOY) }\end{array}$ & $95 \% \mathrm{CI}$ & $b(\mathrm{~d})$ & $95 \% \mathrm{CI}$ & $\begin{array}{c}D_{\max } \\
(\mathrm{DOY})\end{array}$ \\
\hline \multirow[t]{6}{*}{0} & \multirow[t]{2}{*}{1.5} & ns & & $\mathrm{ns}$ & & 79 \\
\hline & & 95.6 & $47.7,143.4$ & 7.16 & $5.09,9.23$ & 79 \\
\hline & \multirow[t]{2}{*}{4} & 62.3 & $61.7,62.8$ & 4.22 & $3.79,4.65$ & 65 \\
\hline & & ns & & 10.48 & $4.47,16.49$ & 79 \\
\hline & \multirow[t]{2}{*}{10} & 63.0 & $60.0,66.1$ & 7.28 & $5.36,9.19$ & 65 \\
\hline & & 62.6 & $57.3,67.8$ & 8.94 & $5.85,12.03$ & 65 \\
\hline \multirow[t]{6}{*}{6} & \multirow[t]{2}{*}{1.5} & 57.1 & $54.1,60.1$ & 2.53 & $2.21,2.84$ & 58 \\
\hline & & 54.9 & $54.2,55.6$ & 1.62 & $1.29,1.96$ & 58 \\
\hline & \multirow[t]{2}{*}{4} & 56.0 & $55.6,56.4$ & 2.37 & $2.08,2.65$ & 58 \\
\hline & & 57.8 & $57.5,58.0$ & 2.19 & $1.81,2.57$ & 58 \\
\hline & \multirow[t]{2}{*}{10} & 56.7 & $56.1,57.2$ & 2.66 & $2.14,3.18$ & 58 \\
\hline & & 56.8 & $55.8,57.9$ & 3.08 & $2.18,3.99$ & 58 \\
\hline
\end{tabular}



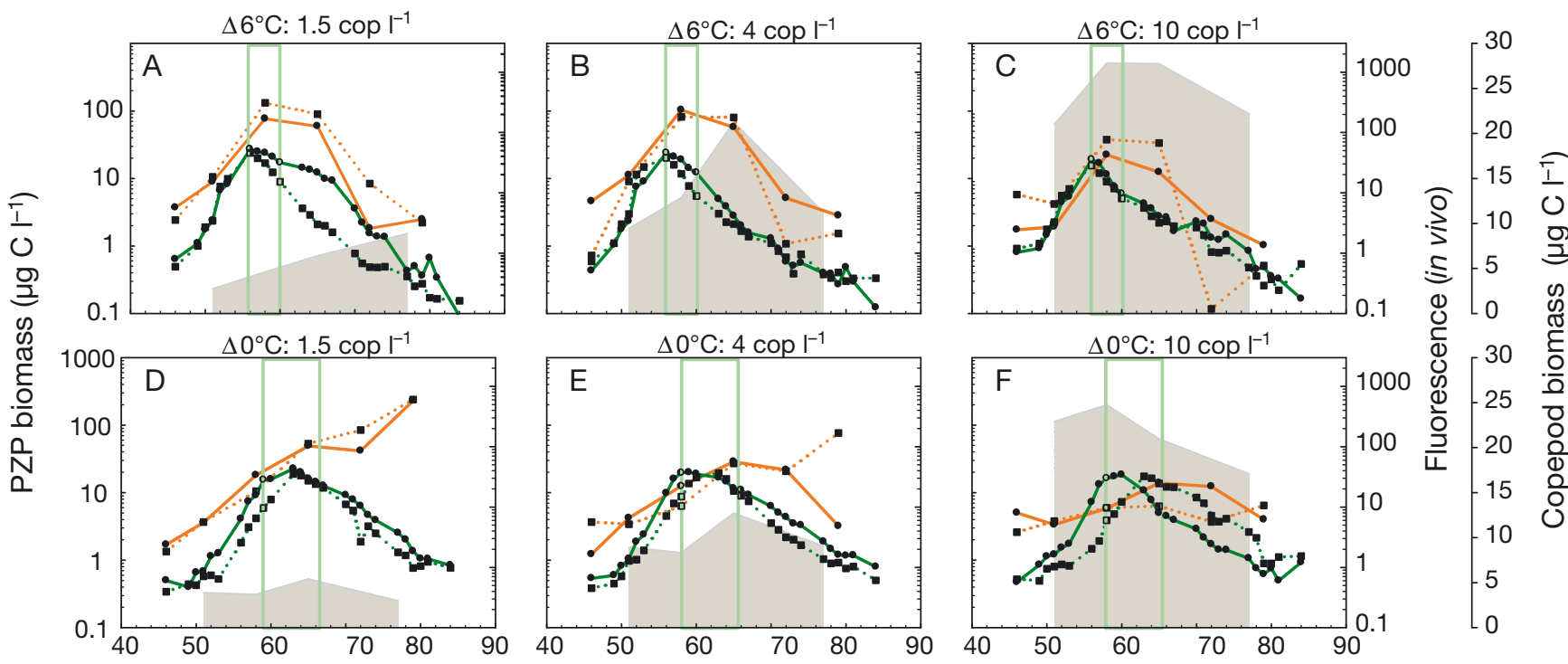

Fig. 2. Protozooplankton (PZP) biomass (orange lines; replicate A: solid line, replicate B: dotted line), phytoplankton fluorescence (in vivo) (green lines; replicate A: solid line, replicate B: dotted line) and mean copepod (cop) biomass per treatment (grey areas). Vertical green boxes illustrate the periods of peak timing of phytoplankton biomass

Table 3. ANCOVA results, calculated with temperature as the categorical factor, log zooplankton initial abundance as the quantitative factor and the interaction term, as well as bloom timing, duration and intensity as dependent variables

\begin{tabular}{|lrccrrrrr|}
\hline Variable & $F_{\text {Temp }}$ & $\mathrm{p}_{\text {Temp }}$ & $F_{\text {Copepod density }}$ & $\mathrm{p}_{\text {Copepod density }}$ & $F_{\text {Interaction }}$ & $\mathrm{p}_{\text {Interaction }}$ & $F_{\text {Model }}$ & $\mathrm{p}_{\text {Model }}$ \\
\hline Bloom timing $\left(x_{0}\right)$ & 11.73 & $<0.025$ & 4.05 & 0.09 & 4.45 & 0.08 & 229.61 & $<0.025$ \\
Bloom duration $(b)$ & 9.41 & $<0.025$ & 0.55 & 0.48 & 0.01 & 0.97 & 28.81 & $<0.025$ \\
Bloom intensity $\left(B_{\mathrm{P}}\right.$ at $\left.D_{\max }\right)$ & 13.02 & $<0.01$ & 42.26 & $<0.01$ & 11.55 & $<0.01$ & 97.08 & $<0.01$ \\
\hline
\end{tabular}
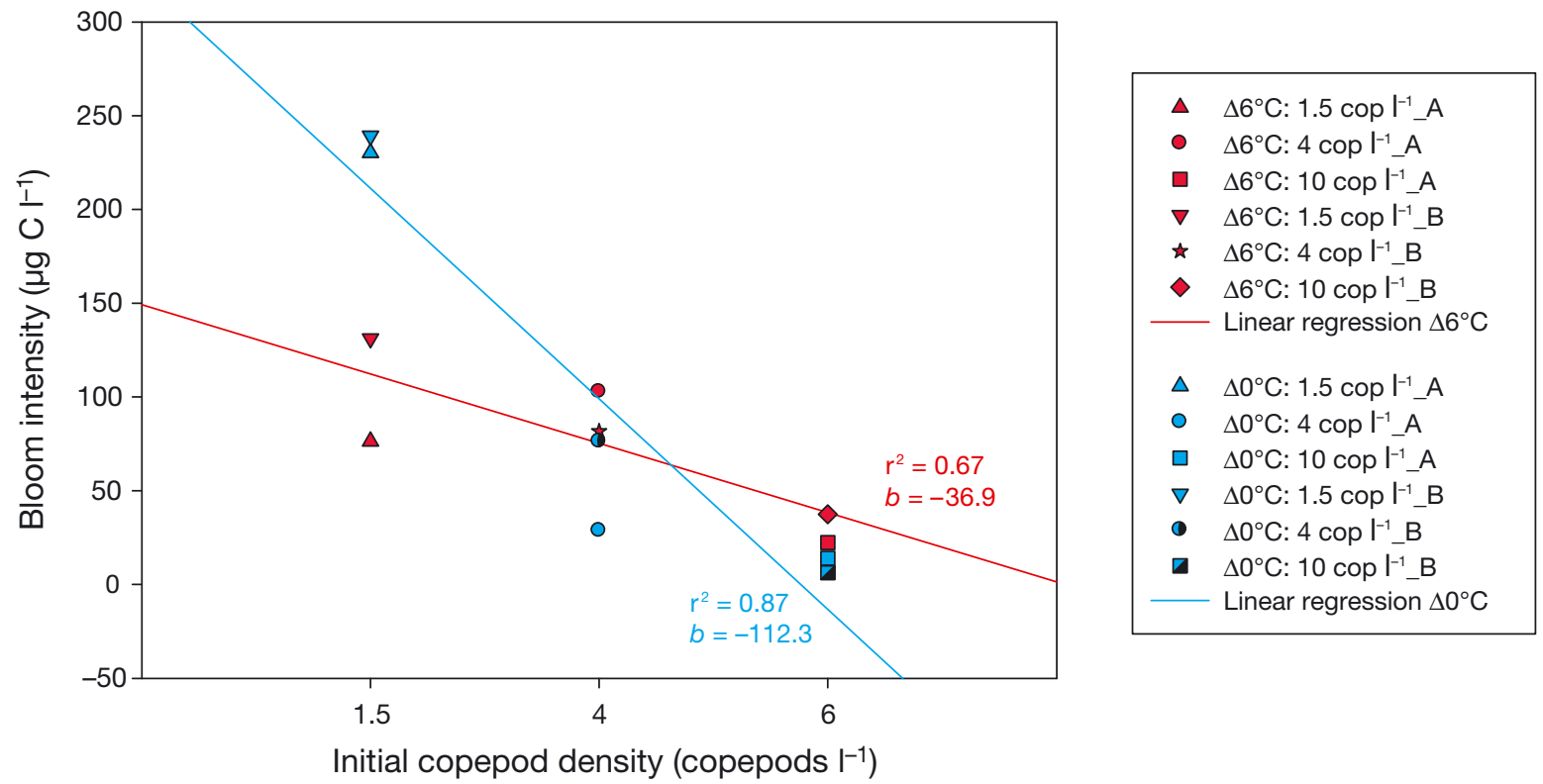

Fig. 3. The relationship between initial copepod (cop) density and protozooplankton biomass at $D_{\max }$ in the $\Delta 6^{\circ} \mathrm{C}$ and $\Delta 0^{\circ} \mathrm{C}$ treatments (replicates A and B). Details of the regressions are shown 


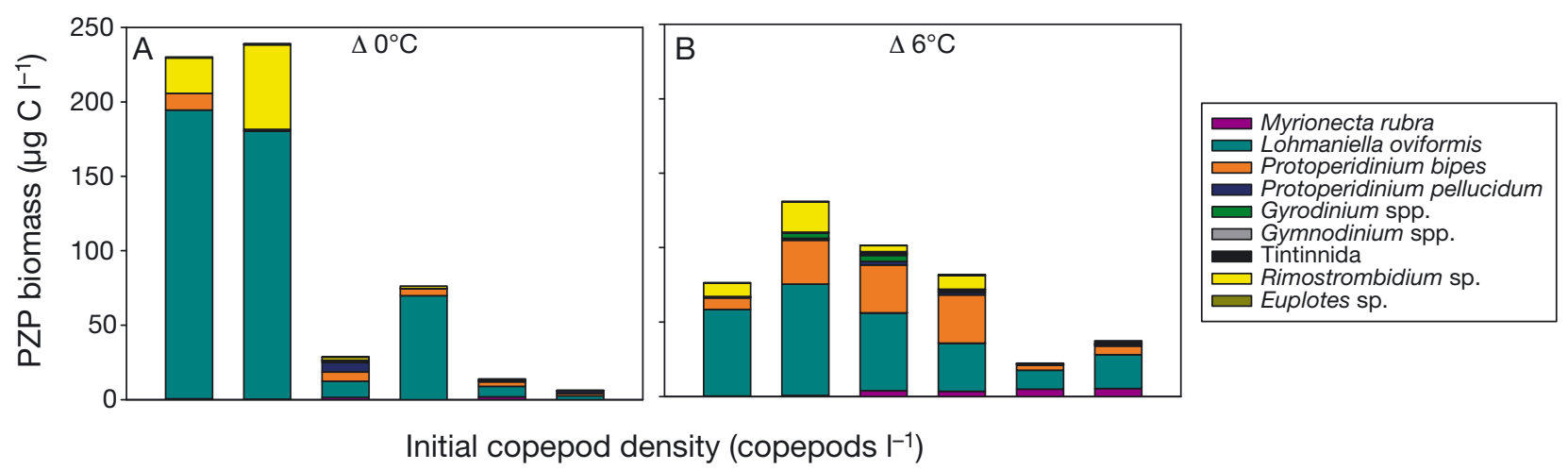

Fig. 4. Species-specific protozooplankton (PZP) biomass at the time of the PZP biomass maximum $\left(D_{\text {max }}\right)$ in $(\mathrm{A})$ the $\Delta 0^{\circ} \mathrm{C}$ treatments and (B) the $\Delta 6^{\circ} \mathrm{C}$ treatments

the $\Delta 0^{\circ} \mathrm{C}$ treatments with low copepod densities (Fig. 4A). Overall, increasing copepod densities led to reduced $B_{\mathrm{P}}$ at $D_{\max }$ in both temperature regimes (Fig. 4A,B).

Proportions of the different PZP size classes (dinoflagellates $>30 \mu \mathrm{m}$, dinoflagellates $<30 \mu \mathrm{m}$, ciliates $>30 \mu \mathrm{m}$ and ciliates $<30 \mu \mathrm{m}$ ) are given in Fig. 5 . ANCOVAs on the different PZP groups and size classes showed that the factor copepod density significantly affected the response of ciliate biomass ( $p$ $<0.01)$ and ciliates $<30 \mu \mathrm{m}(\mathrm{p}<0.01)$ at $D_{\max }$, while the factor 'temperature' and the interaction term did not have any significant impact (Table 4). Dinoflagellates and all other PZP size classes did not show any significant effects in relation to copepod density and/or temperature.

\section{DISCUSSION}

While reduced time lags between phytoplankton and PZP occurrence under elevated temperature conditions are considered typical phenomena (Aberle et al. 2007, 2012, Winder et al. 2012), the interactions between warming and the top-down effects of mesozooplankton are not clear yet. One of the key questions on the responses of plankton communities to warming is whether grazing pressure can be strong enough to prevent a phytoplankton bloom in early spring, as has been hypothesized for delayed spring blooms during warmer late winter/early spring periods in situ (Wiltshire \& Manly 2004). Here, we observed clear phytoplankton bloom formation during early spring under all combinations of temperature and copepod density irrespective of an advanced peak timing of PZP in the warmer mesocosms and overall grazer densities. This suggests the complex nature of spring bloom phenomena, which are influenced by a multitude of factors (e.g. PZP-mesozooplankton interactions, selective feeding of zooplankton).

\section{Effects of overwintering copepod density}

While copepod densities did not affect the timing and duration of the PZP bloom, the bloom intensity was negatively affected by increasing copepod density. Thus, Hypothesis 1, stating that overwintering copepod densities will affect PZP biomass was partially confirmed. To date, it is accepted knowledge that copepods suppress PZP efficiently and that omnivory plays a major role in copepod feeding behaviour (Jonsson \& Tiselius 1990, Stoecker \& Capuzzo 1990, Kleppel 1993, Calbet \& Landry 1999, Sommer et al. 2005). Using PZP as an additional food item has 3 advantages for copepods: (1) broadening the food spectrum and thereby increasing the amount of available food, (2) suppressing resource competitors sensu 'eating your competitor strategy' (Thingstad et al. 1996) and (3) 'trophic upgrading' which results by e.g. conditioning the lipid content and lipid species of the food (Klein Breteler et al. 1999, Tang \& Taal 2005) or buffering nutritional imbalances by heterotrophic protists which function as trophic intermediaries between phytoplankton and secondary consumers (Stoecker \& Egloff 1987, Malzahn et al. 2010). Especially in nutrient-depleted situations, phytoplankton show a high carbon to nutrient ratio (Goldman et al. 1979). This creates an imbalance between the carbon and nutrient supply by the phytoplankton and the demand of consumers. This imbalance is usually reflected by the reduced growth and reproductive rates of the consumer (Elser et al. 2000, Malzahn \& Boersma 2012). From a copepods' point of view, the ability to feed on an interme- 

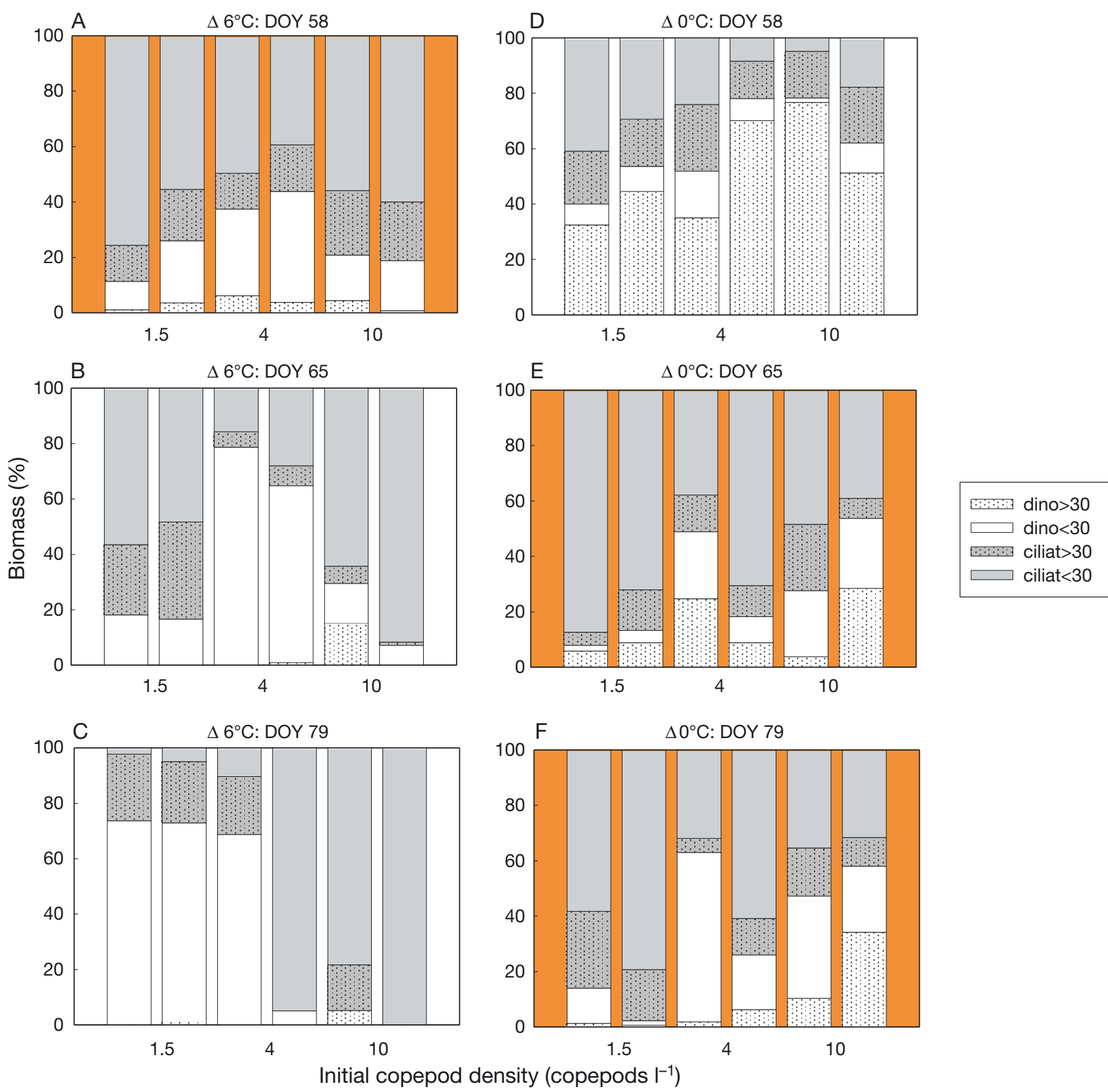

Fig. 5. Proportion of the different protozooplankton (PZP) size classes at specific times during the experiment (DOY 58, 65 and 79) at 2 different temperature regimes and 3 initial copepod densities. PZP size classes: heterotrophic dinoflagellates $>30 \mu \mathrm{m}$, heterotrophic dinoflagellates $<30 \mu \mathrm{m}$, ciliates $>30 \mu \mathrm{m}$ and ciliates $<30 \mu \mathrm{m}$. Orange background indicates $D_{\text {max }}$ the peak timing of PZP biomass $\left(\Delta 6^{\circ} \mathrm{C}\right.$ treatments: $D_{\max }$ on DOY $58 ; \Delta 0^{\circ} \mathrm{C}$ treatments: $D_{\max }$ on DOY 65 or 79$)$

Table 4. ANCOVA on various variables (biomass) at $D_{\max }$, with temperature as the categorical factor, log zooplankton initial abundance as the quantitative factor and the interaction term

\begin{tabular}{|lcccccccc|}
\hline Variable & $F_{\text {Temperature }}$ & $\mathrm{p}_{\text {Temperature }}$ & $F_{\text {Copepod density }}$ & $\mathrm{p}_{\text {Copepod density }}$ & $F_{\text {Interaction }}$ & $\mathrm{p}_{\text {Interaction }}$ & $F_{\text {Model }}$ & $\mathrm{p}_{\text {Model }}$ \\
\hline Dinoflagellates $>30 \mu \mathrm{m}$ & 0.87 & 0.38 & 0.75 & 0.41 & 0.44 & 0.53 & 5.33 & $<0.01$ \\
Dinoflagellates $<30 \mu \mathrm{m}$ & 5.79 & 0.04 & 2.88 & 0.13 & 1.23 & 0.30 & 14.70 & $<0.01$ \\
Ciliates $>30 \mu \mathrm{m}$ & 1.17 & 0.31 & 4.49 & 0.07 & 1.07 & 0.33 & 13.69 & $<0.01$ \\
Ciliates $<30 \mu \mathrm{m}$ & 6.21 & 0.04 & 13.31 & $<0.01$ & 3.99 & 0.08 & $34.69<0.01$ \\
\hline
\end{tabular}


diary consumer might indeed mean lower food availability. But, feeding on organisms which already buffer nutritional imbalances to a large degree will, in turn, benefit the secondary consumer (Malzahn et al. 2010). As shown by Löder et al. (2011), the feeding preferences of copepods are rather flexible, and the question whether they prefer phytoplankton instead of PZP strongly depends on the community composition of the food sources, as well as on the nutrient status in the water column, which affects the quality of food items preyed upon by consumers.

Further, we hypothesized that alterations in overwintering copepod densities will not only affect PZP biomass per se, but also PZP community composition and/or size classes due to differential grazing of copepods. In our study, we found a strong negative effect of increasing copepod densities on ciliate biomass, and, more specifically, a strong suppression of small-sized ciliates (ciliates $<30 \mu \mathrm{m}$ ). In general, a selectivity of omnivorous copepods for ciliates has often been reported (Nejstgaard et al. 2001, Vincent \& Hartmann 2001, Jakobsen et al. 2005, Schnetzer \& Caron 2005). Such a feeding preference has been linked to the favorable nutritional quality of ciliates as opposed to phytoplankton prey, thus stressing the relevance of ciliates in the diets of copepods such as Acartia sp., the dominant copepod species in our mesocosms (Stoecker \& Egloff 1987, Gifford \& Dagg 1988, Kleppel et al. 1991, Kleppel 1993). This is especially true during the decay of a phytoplankton bloom, when nutrients become limited and phytoplankton turns into a poor-quality food item (Löder et al. 2011). The small strobilidiid ciliate Lohmaniella oviformis acted as the main bloom-forming species during this mesocosm experiment and contributed almost exclusively to the ciliate size class $<30 \mu \mathrm{m}$. L. oviformis is considered a typical ciliate species during the winter-spring transition (Johansson et al. 2004, Aberle et al. 2007, 2012), and, due to its bloom formation, it can be speculated that it served as an abundant and well-edible prey item for copepods in our mesocosms. So far, many omnivorous copepods have been shown to feed selectively on specific ciliate species (Stoecker \& Capuzzo 1990, Nishibe et al. 2010, Wu et al. 2010) and, among other selection criteria (e.g. swimming behaviour, nutritional status of the prey), size seems to play only a minor role with regard to the feeding behaviour of copepods (Jonsson \& Tiselius 1990, Broglio et al. 2001, Gismervik 2006). Therefore, it seems more likely that the preference for ciliates $<30 \mu \mathrm{m}$ in our mesocosms resulted from selective grazing of copepods (e.g. the calanoid copepods Acartia sp.) on the ciliate L. oviformis rather than from size-specific copepod predation. This is in line with studies on the feeding behaviour of Acartia sp., showing high clearance rates and a high capture efficiency when preying upon $L$. oviformis (Tiselius 1989, Gismervik 2006).

In contrast to the strong suppression of ciliates by copepods, heterotrophic dinoflagellates remained unaffected by copepod densities in our study. Although both thecate and athecate dinoflagellates are known to be consumed by copepods (Sommer et al. 2005), a preference for ciliates over dinoflagellates is documented in the literature in general (Vincent \& Hartmann 2001, Schnetzer \& Caron 2005) and for Acartia sp. more specifically (Jakobsen et al. 2005). Here, we consider the thecate dinoflagellate Protoperidinium bipes, which occurred at moderate abundances in our mesocosms, as a less preferred food item in our mesocosm, which resulted in a release from grazing pressure by copepods.

\section{Combined effects of warming and copepod density}

Hypotheses 2 and 3 aimed at analysing trends in energy transfer at the interface between microbial and classical food chains in the light of future warming conditions. We hypothesized that warming at high copepod densities will lead to a strong top-down control by copepods, thus supporting the PZPs' role as a 'trophic link' by channelling carbon consumed by PZP through the 'classic' food chain. Warming at low copepod densities, however, should hypothetically lead to an earlier timing of PZP, thus functioning as a 'trophic sink' due to reduced time-lags between phytoplankton and PZP production.

With regard to Hypothesis 2, we found a strong effect of temperature and copepod density on the bloom intensity of PZB. At high temperatures, PZP was suppressed substantially throughout all copepod treatments, with a slightly stronger impact on PZP bloom intensity at high copepod density. At low temperature conditions and the lowest copepod density, however, PZP fully escaped top-down control by copepods. Thus, our hypothesis that the combined effects of warming and overwintering copepod densities will lead to stronger top-down control in the plankton was confirmed. Our findings are supported by the results of other studies showing that enhanced grazing by copepods as a result of higher metabolic activities is expected in relation to warming (Isla et al. 2008, O'Connor et al. 2009), and, consequently, higher copepod densities at elevated temperatures are likely to result in a stronger suppression of PZP. 
At low temperatures and low overwintering copepod density, however, PZP growth rates seemed to exceed grazing losses, thus leading to a release from copepod predation and enabling PZP to form intense blooms in the cold mesocosms.

Further, we found a strong effect of temperature on PZP bloom timing and bloom duration at elevated temperatures, leading to an advanced peak timing, but shorter bloom duration, irrespective of copepod densities. This leads to a rejection of Hypothesis 3, assuming that warming in combination with copepod density will result in an earlier timing and reduced time-lags between phytoplankton and PZP. Simulations conducted during a previous study using the same mesocosm set-up showed that the reduction of time lags between primary producers and consumers increases with increasing $Q_{10}$ values of PZP (Aberle et al. 2012). Consequently, warming alone strengthens the match between PZP and its algal prey which, in turn, promotes the phytoplankton-PZP link. In general, PZP is known to suppress phytoplankton standing stocks efficiently (Sherr \& Sherr 2007, 2009, Löder et al. 2011). Based on an analysis from the same mesocosm study, Sommer \& Lewandowska (2011) reported a shift in phytoplankton composition from larger diatoms to smaller, flagellated phytoplankton under elevated temperature conditions. Such a shift in phytoplankton community composition might have created a positive feedback loop, where PZP growth rates were boosted not only by elevated temperatures, but also by a phytoplankton community that contained optimal prey for PZP. As an example, the rapid growth and decline in $L$. oviformis biomass might be related to an overexploitation of algae between 2 and $15 \mu \mathrm{m}$, the preferred food of this ciliate species (Jonsson 1986, Christaki et al. 1998). In the given case, enhanced grazing by the ciliate $L$. oviformis on small-sized phytoplankton might channel more energy away from the direct phytoplankton-copepod link. Since L. oviformis is considered to serve as a preferred food item for copepods (Tiselius 1989, Gismervik 2006) and its growth will rather benefit from warming conditions, it seems more likely that $L$. oviformis will act increasingly as a 'trophic link' to copepods (and copepod-feeding fish). However, a completely different picture might evolve if other PZP groups such as heterotrophic dinoflagellates are promoted by changes in environmental conditions. Since heterotrophic dinoflagellates are considered efficient consumers of bloomforming diatoms (Sherr \& Sherr 2007, Calbet 2008), direct feeding competition with copepods would occur, thus creating a 'trophic sink' and reducing energy flow up the food web. Such a trend would support the predictions of Berglund et al. (2007) indicating a reduced energy transfer to higher trophic levels in relation to climate change when the direct pathway from phytoplankton to mesozooplankton is intermitted by an intermediary trophic level comprised of heterotrophic dinoflagellates.

\section{CONCLUSIONS}

The results of the present study provide evidence that warming in combination with increases in overwintering copepod densities will have considerable impact on the bloom intensity of PZP and top-down control mechanisms in the plankton. While warming will support the phytoplankton-PZP link in general, the distinct trophic roles of ciliates as opposed to dinoflagellates must also be taken into consideration. While stimulated growth of ciliates might enhance energy transfer efficiency to higher trophic levels, dinoflagellates might act as more of a 'trophic sink' in future plankton communities by supporting microbial pathways and reducing energy transfer up the food web as well as reducing export production to the deep oceans.

Acknowledgements. This project was funded by the Priority Programme 1162 'AQUASHIFT' of the German Research Foundation (DFG). The authors thank T. Hansen, C. Meyer and $\mathrm{H}$. Tomanetz for technical support. Mathias Haunost is thanked for his help with protozooplankton enumeration.

\section{LITERATURE CITED}

Aberle N, Lengfellner K, Sommer U (2007) Spring bloom succession, grazing impact and herbivore selectivity of ciliate communities in response to winter warming. Oecologia 150:668-681

Aberle N, Bauer B, Lewandowska A, Gaedke U, Sommer U (2012) Warming induces shifts in microzooplankton phenology and reduces time-lags between phytoplankton and protozoan production. Mar Biol 159:2441-2453

Behrends G (1996) Long-term investigation of seasonal mesozooplankton dynamics in Kiel Bight. In: Andrushaitis A (ed) Proceedings of the 13th Symposium of the Baltic Marine Biologists. Institute of Aquatic Ecology, University of Latvia, Riga, p 93-96

$>$ Berglund J, Muren U, Bamstedt U, Andersson A (2007) Efficiency of a phytoplankton-based and a bacteria-based food web in a pelagic marine system. Limnol Oceanogr 52:121-131

$>$ Brock TD (1981) Calculating solar radiation for ecological studies. Ecol Modell 14:1-19

Broglio E, Johansson M, Jonsson PR (2001) Trophic interaction between copepods and ciliates: effects of prey swimming behavior on predation risk. Mar Ecol Prog Ser 220:179-186 
Brown JH, Gillooly JF, Allen AP, Savage VM, West GB (2004) Toward a metabolic theory of ecology. Ecology 85: 1771-1789

Calbet A (2008) The trophic roles of microzooplankton in marine systems. ICES J Mar Sci 65:325-331

Calbet A, Landry MR (1999) Mesozooplankton influences on the microbial food web: direct and indirect trophic interactions in the oligotrophic open ocean. Limnol Oceanogr 44:1370-1380

> Christaki U, Dolan JR, Pelegri S, Rassoulzadegan F (1998) Consumption of picoplankton-size particles by marine ciliates: effects of physiological state of the ciliate and particle quality. Limnol Oceanogr 43:458-464

Edwards M, Richardson AJ (2004) Impact of climate change on marine pelagic phenology and trophic mismatch. Nature 430:881-884

- Elser JJ, Fagan WF, Denno RF, Dobberfuhl DR and others (2000) Nutritional constraints in terrestrial and freshwater food webs. Nature 408:578-580

Fenchel T, Finlay BJ (1983) Respiration rates in heterotrophic, free-living protozoa. Microb Ecol 9:99-122

Foissner W, Berger H, Kohmann F (1991-1995) Taxonomische und ökologische Revision der Ciliaten des Saprobiensystems, Bänder I-IV. Informationsberichte, Bayerisches Landesamt für Wasserwirtschaft, Munich

Gerten D, Adrian R (2001) Differences in the persistency of the North Atlantic Oscillation signal among lakes. Limnol Oceanogr 46:448-455

Gifford DJ (1991) The protozoan-metazoan trophic link in pelagic ecosystems. J Protozool 38:81-86

Gifford DJ, Dagg MJ (1988) Feeding of the estuarine copepod Acartia tonsa-carnivory vs herbivory in natural microplankton assemblages. Bull Mar Sci 43:458-468

Gismervik I (2006) Top-down impact by copepods on ciliate numbers and persistence depends on copepod and ciliate species composition. J Plankton Res 28:499-507

Goldman JC, McCarthy JJ, Peavey DG (1979) Growth rate influence on the chemical composition of phytoplankton in oceanic waters. Nature 279:210-215

> Hillebrand H, Duerselen CD, Kirschtel D, Pollingher U, Zohary $\mathrm{T}$ (1999) Biovolume calculation for pelagic and benthic microalgae. J Phycol 35:403-424

IPCC (Intergovernmental Panel on Climate Change) (2007) Clim Change: 2007. The physical science basis. Contribution of Working Group I to the 4th assessment report of the Intergovernmental Panel on Climate Change. IPCC, Cambridge

> Irigoien X, Flynn KJ, Harris RP (2005) Phytoplankton blooms: a 'loophole' in microzooplankton grazing impact? J Plankton Res 27:313-321

> Isla JA, Lengfellner K, Sommer U (2008) Physiological response of the copepod Pseudocalanus sp. in the Baltic Sea at different thermal scenarios. Glob Change Biol 14: 895-906

> Jakobsen HH, Halvorsen E, Hansen BW, Visser AW (2005) Effects of prey motility and concentration on feeding in Acartia tonsa and Temora longicornis: the importance of feeding modes. J Plankton Res 27:775-785

> Johansson M, Gorokhova E, Larsson U (2004) Annual variability in ciliate community structure, potential prey and predators in the open northern Baltic Sea proper. J Plankton Res 26:67-80

> Jonsson PR (1986) Particle size selection, feeding rates and growth dynamics of marine planktonic oligotrichous ciliates (Ciliophora: Oligotrichina). Mar Ecol Prog Ser 33:
265-277

Jonsson PR, Tiselius P (1990) Feeding behaviour, prey detection and capture efficiency of the copepod Acartia tonsa feeding on planktonic ciliates. Mar Ecol Prog Ser 60:35-44

Kahl A (1932) Urtiere oder Protozoa. I. Wimpertiere oder Ciliata (Infusoria). Tierwelt Deutschlands und der angrenzenden Meeresteile, Book 18. G. Fischer, Jena

> Keller AA, Oviatt CA, Walker HA, Hawk JD (1999) Predicted impacts of elevated temperature on the magnitude of the winter-spring phytoplankton bloom in temperate coastal waters: a mesocosm study. Limnol Oceanogr 44:344-356

Klein Breteler WCM, Schogt N, Baas M, Schouten S, Kraay GW (1999) Trophic upgrading of food quality by protozoans enhancing copepod growth: role of essential lipids. Mar Biol 135:191-198

Kleppel GS (1993) On the diets of calanoid copepods. Mar Ecol Prog Ser 99:183-195

> Kleppel GS, Holliday DV, Pieper RE (1991) Trophic interactions between copepods and microzooplankton: a question about the role of diatoms. Limnol Oceanogr 36: $172-178$

Lewandowska A, Hillebrand H, Lengfellner K, Sommer U (2014) Temperature effects on phytoplankton diversity the zooplankton link. J Sea Res 85:359-364

Löder MGJ, Meunier C, Wiltshire KH, Boersma M, Aberle N (2011) The role of ciliates, heterotrophic dinoflagellates and copepods in structuring spring plankton communities at Helgoland Roads, North Sea. Mar Biol 158: 1551-1580

Malzahn AM, Boersma M (2012) Effects of poor food quality on copepod growth are dose dependent and nonreversible. Oikos 121:1408-1416

> Malzahn AM, Hantzsche F, Schoo KL, Boersma M, Aberle N (2010) Differential effects of nutrient-limited primary production on primary, secondary or tertiary consumers. Oecologia 162:35-48

McGowan JA, Bograd SJ, Lynn RJ, Miller AJ (2003) The biological response to the 1977 regime shift in the California Current. Deep-Sea Res II 50:2567-2582

> Montagnes DJS, Lessard EJ (1999) Population dynamics of the marine planktonic ciliate Strombidinopsis multiauris: its potential to control phytoplankton blooms. Aquat Microb Ecol 20:167-181

$>$ Montagnes DJS, Kimmance SA, Atkinson D (2003) Using Q10: Can growth rates increase linearly with temperature? Aquat Microb Ecol 32:307-313

Mueller H, Geller W (1993) Maximum growth rates of aquatic ciliated protozoa: the dependence on body size and temperature reconsidered. Arch Hydrobiol 126: 315-327

> Nejstgaard JC, Hygum BH, Naustvoll LJ, Bamstedt U (2001) Zooplankton growth, diet and reproductive success compared in simultaneous diatom- and flagellatemicrozooplankton-dominated plankton blooms. Mar Ecol Prog Ser 221:77-91

Nishibe Y, Kobari T, Ota T (2010) Feeding by the cyclopoid copepod Oithona similis on the microplankton assemblage in the Oyashio region during spring. Plankton Benthos Res 5:74-78

- O'Connor MI, Piehler MF, Leech DM, Anton A, Bruno JF (2009) Warming and resource availability shift food web structure and metabolism. PLoS Biol 7:e1000178

Putt M, Stoecker DK (1989) An experimentally determined 
carbon:volume ratio for marine 'oligotrichous' ciliates from estuarine and coastal waters. Limnol Oceanogr 34: 1097-1103

Rollwagen-Bollens G, Gifford S, Bollens SM (2011) The role of protistan microzooplankton in the Upper San Francisco Estuary planktonic food web: source or sink? Estuaries Coasts 34:1026-1038

Rose JM, Caron DA (2007) Does low temperature constrain the growth rates of heterotrophic protists? Evidence and implications for algal blooms in cold waters. Limnol Oceanogr 52:886-895

Schnetzer A, Caron DA (2005) Copepod grazing impact on the trophic structure of the microbial assemblage of the San Pedro Channel, California. J Plankton Res 27: 959-971

Scott FJE (2005) Antarctic marine protists. ABRS, Canberra

Sherr EB, Sherr BF (2007) Heterotrophic dinoflagellates: a significant component of microzooplankton biomass and major grazers of diatoms in the sea. Mar Ecol Prog Ser 352:187-197

Sherr EB, Sherr BF (2009) Capacity of herbivorous protists to control initiation and development of mass phytoplankton blooms. Aquat Microb Ecol 57:253-262

Smol JP, Wolfe AP, Birks HJB, Douglas MSV and others (2005) Climate-driven regime shifts in the biological communities of arctic lakes. Proc Natl Acad Sci USA 102: 4397-4402

Sommer U, Lengfellner K (2008) Climate change and the timing, magnitude, and composition of the phytoplankton spring bloom. Glob Change Biol 14:1199-1208

Sommer U, Lewandowska A (2011) Climate change and the phytoplankton spring bloom: warming and overwintering zooplankton have similar effects on phytoplankton. Glob Change Biol 17:154-162

Sommer U, Hansen T, Blum O, Holzner N, Vadstein O, Stibor $\mathrm{H}$ (2005) Copepod and microzooplankton grazing in mesocosms fertilised with different $\mathrm{Si} \mathrm{N}$ ratios: no overlap between food spectra and Si:N influence on zooplankton trophic level. Oecologia 142:274-283

Sommer U, Aberle N, Lengfellner K, Lewandowska A (2012) The Baltic Sea spring phytoplankton bloom in a changing climate: an experimental approach. Mar Biol 159: 2479-2490

Stoecker DK, Capuzzo JM (1990) Predation on protozoa: its importance to zooplankton. J Plankton Res 12:891-908

Stoecker DK, Egloff DA (1987) Predation by Acartia tonsa dana on planktonic ciliates and rotifers. J Exp Mar Biol Ecol 110:53-68

Editorial responsibility: Edward Durbin,

Narragansett, Rhode Island, USA
Straile D, Adrian R (2000) The North Atlantic Oscillation and plankton dynamics in two European lakes - two variations on a general theme. Glob Change Biol 6:663-670

Strüder-Kypke MC, Kypke ER, Agatha S, Warwick J, Montagnes DJS (2002) Guide to UK coastal planktonic ciliates. www.zooplankton.cn/ciliate/contents.htm

> Tang KW, Taal M (2005) Trophic modification of food quality by heterotrophic protists: species-specific effects on copepod egg production and egg hatching. J Exp Mar Biol Ecol 318:85-98

Thingstad TF, Havskum H, Garde K, Riemann B (1996) On the strategy of 'eating your competitor': a mathematical analysis of algal mixotrophy. Ecology 77:2108-2118

- Tiselius P (1989) Contribution of aloricate ciliates to the diet of Acartia clausi and Centropages hamatus in coastal waters. Mar Ecol Prog Ser 56:49-56

Tomas CRE (1996) Identifying marine diatoms and dinoflagellates. Academic Press, San Diego, CA

Utermöhl H (1958) Zur Vervollkommnung der quantitativen Phytoplankton-Methodik. Mitt Int Ver Theor Angew Limnol 9:1-38

> Vincent D, Hartmann HJ (2001) Contribution of ciliated microprotozoans and dinoflagellates to the diet of three copepod species in the Bay of Biscay. Hydrobiologia 443: 193-204

Weisse T, Montagnes DJS (1998) Effect of temperature on inter- and intraspecific isolates of Urotricha (Prostomatida, Ciliophora). Aquat Microb Ecol 15:285-291

Weyhenmeyer GA (2001) Warmer winters: Are planktonic algal populations in Sweden's largest lakes affected? Ambio 30:565-571

Weyhenmeyer GA, Blenckner T, Pettersson K (1999) Changes of the plankton spring outburst related to the North Atlantic Oscillation. Limnol Oceanogr 44:1788-1792

Wiltshire KH, Manly BFJ (2004) The warming trend at Helgoland Roads, North Sea: phytoplankton response. Helgol Mar Res 58:269-273

> Wiltshire KH, Malzahn AM, Wirtz K, Greve W and others (2008) Resilience of North Sea phytoplankton spring bloom dynamics: an analysis of long-term data at Helgoland Roads. Limnol Oceanogr 53:1294-1302

> Winder M, Berger SA, Lewandowska A, Aberle N, Lengfellner K, Sommer U, Diehl S (2012) Spring phenological responses of marine and freshwater plankton to changing temperature and light conditions. Mar Biol 159:2491-2501

Wu CH, Dahms HU, Buskey EJ, Strickler JR, Hwang JS (2010) Behavioral interactions of the copepod Temora turbinata with potential ciliate prey. Zool Stud 49:157-168

Submitted: August 13, 2013; Accepted: October 16, 2014

Proofs received from author(s): December 10, 2014 